\title{
MÃOS À OBRA COLETIVA - A PARTICIPAÇÃO
}

Em tópico precedente, cogitei a hipótese de que um extraterrestre aterrissasse no Brasil no século XXI, se deparando com as mazelas da social democracia que construímos ao longo das últimas três décadas. Proponho agora, como um segundo exercício de imaginação, que substituíssemos o nosso amigo ET por um ateniense do século $\mathrm{V}$ a.C., que tivesse se transportado a algum local deste território brasileiro. No dia anterior, ainda na Grécia antiga, ele havia se reunido na assembleia do povo, a ágora, juntamente com seus concidadãos, a fim de debater questões relevantes sobre a infraestrutura e administração da pólis. A sua presença ali não constituía uma exigência legal, senão um dever cívico, decorrente do profundo sentimento de pertencimento àquela comunidade. Ao aterrissar aqui, todavia, deparou-se com uma arquitetura institucional completamente distinta, cuja base não estava mais respaldada na influência real, direta e constante do povo nos assuntos da cidade, mas na escolha de representantes que deveriam decidir como e quando gastar os recursos públicos. $\mathrm{O}$ que consideramos democracia não lhe parecia nem um pouco com uma democracia. $\mathrm{O}$ ateniense percebeu, com certa inquietude, que aquele status ativo de cidadão havia se reduzido à condição de eleitorado passivo, atado ao ritmo intermitente e incerto das urnas, e estarrecia-se com o fato de que isso não era motivo de insatisfação, mas que, por outro lado, havia se transformado em conformidade.

Aquilo tudo lhe parecia muito estranho. E punha-se a refletir: que direção teria tomado a história para que a soberania política, antes concentrada nas mãos daqueles que lhes deram fundamento [o povo] e por eles exercida permanentemente, houvesse se descolado de tal modo que a participação política se converteu em exceção? 
Conforme veremos, o trajeto à representação política nas democracias atuais foi resultado incontornável das circunstâncias socioculturais que sucederam na maioria das nações, com o advento da explosão demográfica e do pluralismo. Porém, o ponto que o nosso cogitado ateniense reforça é que a participação social não deixa de constituir um elemento essencial para o bom funcionamento de qualquer governo democrático.

Aliás, se tem um fator que oxigena a democracia e lhe dá força para prosperar boas políticas, é a inserção do povo nos assuntos coletivos. Não por acaso, ao dispor sobre os critérios necessários para construção de um processo democrático perfeito, Robert A. Dahl estabelece em primeiro lugar a necessidade de participação efetiva ou, em outras palavras, "que ao longo de todo o processo de tomada de decisões vinculativas, os cidadãos tenham oportunidade adequada e igual de expressar suas preferências quanto ao resultado final, de colocar questóes na agenda política e expressar seus motivos para endossar um resultado e não outro". ${ }^{374}$

Quando os cidadãos não têm formas de utilizar a informação para participar nos processos de tomada de decisões, se reduz a importância da transparência. Por igual, a transparência sem participação pode conduzir à completa frustração: os problemas serão mais facilmente identificados, mas as soluçôes manter-se-ão fora de alcance. Em especial, a transparência sem oportunidades de participação para os grupos mais vulneráveis, pode beneficiar elites e agravar o problema da corrupção.

Tal premência da inserção cidadã está associada à capacidade da sociedade civil de, a curto prazo, utilizar os espaços existentes para reverberar suas demandas, recebendo respostas que poderão ser controladas posteriormente e, a longo prazo, promover melhorias na qualidade das instituiçōes políticas. Os dois aspectos importam, e muito, embora o último esteja mais ligado à ação coletiva estável que precisamos para realizar a transição do modelo de governança particularista ao modelo de integridade e universalismo ético. É que os mecanismos de participação podem ajudar a melhorar o funcionamento das instituições formais, ao incluir o maior número de vozes nas arenas de debate das políticas públicas, permitindo que a distribuiçôes de poder, influência e recursos públicos seja mais equânime e menos propensa à preservação dos privilégios que oportunizam a corrupção como a conhecemos.

Todavia, governo inteiramente participativo que propõe a inclusão de todos nas decisões, após as experiências da antiguidade, não passou de um formato democrático ideal que apenas se concebe no plano das ideias.

374 DAHL, Robert. A. A democracia e seus críticos. São Paulo: WMF Martins Fontes, 2012. 
A consolidação dos regimes representativos modernos, desde os movimentos revolucionários do final do século XVIII e meados do século XIX, parte justamente desta compreensão acerca da inviabilidade prática da democracia direta. John Stuart Mill, após explorar todos os benefícios que adviriam da abertura completa do governo à vontade dos governados, conclui, entretanto, que tais benefícios seriam irrealizáveis em comunidades que excedessem as proporções de um pequeno vilarejo, de modo que o tipo de governo perfeito, diante das circunstâncias, seria o representativo. ${ }^{375}$ Robert Dahl parte do mesmo pressuposto para defender os valores democráticos. Segundo ele, a representatividade é a única solução possível nas democracias de grande escala para o problema da autorização, pois, como um atleta que, ao engordar, perde a rapidez e agilidade, e não consegue mais participar dos jogos, a enormidade de nosso demos não é adequada à democracia [direta].

Ao sobrelevar o aspecto procedimental do regime ou, melhor dizendo, a forma como as decisóes que dizem respeito à coletividade devem ser tomadas, em detrimento da substância e dos resultados que elas estão aptas a produzir, acaba prevalecendo, como concepção hegemônica, o arranjo institucional da democracia liberal-representativa.

Se por um lado, no último século, não restaram controvérsias acerca da preferência pela democracia como forma de governo, de modo que até ditaduras utilizam uma pitada ou duas de democracia como pretexto para retirar sua legitimidade, por outro, a proposta que prevaleceu ao final da década de quarenta centralizou a ideia de soberania popular nas formas eleitorais de escolha de governos, restringindo os mecanismos de participação direta. Não se cogitava mais da gestão participativa da qual falava Rousseau.

Neste contexto, foram projetados modelos minimalistas de democracia, cujo cerne compreendia um procedimento de escolha de agentes políticos e a disputa entre eles para angariar votos, sem que as possibilidades de participação da sociedade civil alcançassem outros espaços não eleitorais. ${ }^{376} \mathrm{Em}$ palavras menos congestionadas, tudo que concerne à democracia acabava se resumindo a um método político de escolha dos representantes.

$\mathrm{Na}$ acepção mais moderna, a redução da esfera de atuação do cidadão partia ora da constatação de sua incapacidade intelectual e organizativa para lidar, por si mesmo, com questóes públicas complexas, devendo limitar-se o exercício da cidadania à escolha de líderes que fizessem estas decisões (Schumpeter), ora do aumento da complexidade social nas democracias contemporâneas (Bobbio).

375 MILL, John Stuart. Consideraçôes sobre o governo representativo. Brasília: Editora UnB, 1984.

376 CAROLE PATEMAN. Participatory democracy revisited. Perspectives on Politics. 10 (1), 2012. 
Portanto, para o problema da necessidade de consenso e aceitação popular à tomada de decisões coletivas, foi dada uma resposta extremamente elitista, que superfaturava os modelos de representação, presumindo que eles conseguiriam suprir por inteiro a necessidade de legitimação social do Estado, ou seja, que as eleições esgotam a autorização que os cidadãos devem conceder às práticas governamentais.

Como era de se esperar, não demorou até que este esquema liberal-representativo imergisse em profunda crise. De mãos atadas, os cidadãos passaram a se distanciar cada vez mais de seus representantes, na mesma proporção em que estes pareciam representar cada vez menos a vontade real dos governados, mas sim interesses exclusivos de grupos políticos e empresariais dominantes. Este rompimento, contudo, não foi obra do acaso. Com o surgimento dos assim denominados estados de bem-estar social, caracterizados pela planificação e presença maior do Estado na prestação de serviço e fornecimento de bens públicos, é natural que houvesse um crescimento exponencial das demandas cidadãs e, por conseguinte, da responsividade à cargo dos governantes, ou seja, da sua capacidade de atender as crescentes necessidades. Adicionalmente, a modernização e o aumento do nível informacional (educacional) dos cidadãos geraram mais expectativas sobre o desempenho governamental. ${ }^{377}$ Sem corresponder a estas expectativas, o governo acaba refletindo na sociedade uma enorme insatisfação. Além disso, o desvelamento da corrupção e dos métodos opacos utilizados para fazer prevalecer alocaçóes clientelistas e acentuou a desconfiança na integridade dos mecanismos tradicionais de representação.

A crescente desigualdade nas décadas recentes, desta feita, colocou em xeque a capacidade dos governos de responder aos desafios contemporâneos. A possibilidade de que não o façam e acabem atendendo principalmente aos interesses dos mais privilegiados tem alimentado algumas revoltas populares em 2016-2017.

Os partidos políticos, que foram concebidos para funcionar como intermediários ou caixas de ressonância da vontade cidadã perante as estruturas formais de poder, acabaram desvirtuados em sua finalidade originária, tornando-se o centro das queixas e o ícone maior do déficit de confiança. A percepção era de que os fins desejados pelo povo eram sempre objeto de alienações e descumprimento por outra vontade que, ocupando e dominando as casas representativas, os traía. ${ }^{378}$

377 NORRIS, Pippa. Democratic deficit: critical citizens revisited. Cambridge University Press, 2011.

378 Paulo Bonavides se refere a este movimento como a repolitização da legitimidade, criadora de uma neocidadania governante, único caminho que permitiria à democracia "sair do círculo vicioso onde se movem, à revelia e à distância do povo, as bancadas congressuais e as organizaçóes 
Fala-se, então, da crise de representatividade, cujo resultado mediato foi questionamento sobre como deve se desenrolar as interações dos cidadãos com o governo, e o avanço das reinvindicações para que a força política das cadeiras parlamentares cedesse lugar à presença mais direta, efetiva e constante da sociedade, superando a concepção fossilizada de cidadania, baseada na garantia formal e vazia de direitos políticos.

No Brasil, não obstante a alternância de períodos liberais incompletos e outros predominantemente estatistas, a relação entre o Estado e a sociedade civil sempre esteve marcada pela crise de legitimidade da representação, acarretando um afastamento entre cidadãos e política e as suas instituições mediadoras (partidos políticos). Dessa relação de desconfiança, surgiu um Estado pouco público, no sentido de abertura, e uma sociedade civil difusa, porém com a esperança viva de poder se associar às decisōes públicas. ${ }^{379}$

Reabrem-se neste contexto - sobretudo a partir do aprofundamento do processo de globalização - questóes que colocam em contraposição a democracia representativa e a democracia direta. De fato, a atual reivindicação da sociedade por mais democracia na maioria dos casos se confunde com uma reinvindicação por mais democracia direta, como se constituísse ideia antagônica ao regime representativo. Tais objeções, designadas por Giovanni Sartori como diretismo, ${ }^{380}$ buscam pressionar as instituições representativas a ceder espaços de decisão que devem ser ocupados pela vontade direta do cidadão.

Tal movimento de reapropriação do poder, no entanto, deve ser articulado a partir de uma ótica diferente: assim como a representação não exclui a necessidade de atuação cidadã permanente, a participação direta não substitui a utilidade da representação política em sociedades plurais e densas. Trata-se, na verdade, da coexistência de modelos dentro de um desenho institucional que dê valor à soberania popular como elemento de legitimidade do ciclo de políticas públicas.

Os cidadãos não almejam uma espécie de cidadania total, que decida sobre tudo e seja onipresente no processo político, pois sabem que pretendendo controlar tudo,

partidárias". BONAVIDES, Paulo. Teoria constitucional da democracia participativa. Por um direito constitucional de luta e resistência, por uma nova hermenêutica, por uma repolitização da legitimidade. São Paulo: Malheiros, 2008.

379 SEGATTO, José Antônio. Política, relaçôes sociais e cidadania. Rio de Janeiro: Contraponto, 2015.

380 SARTORI, Giovanni. En defensa de la representación política. In: CARBONELL, Miguel (Coord.). Democracia y representación: um debate contemporâneo. México: Tribunal Electoral del Poder Judicial de la Federación, 2005. 
acabarão controlando quase-nada. Desejam, sim, ser escutados, informados, tratados com respeito e associados às decisōes. Nessas condições, estão inclusive mais facilmente dispostos a aceitar opçôes que lhes resultem desfavoráveis individualmente.

Em última instância, o ativismo cidadão pode ser encarado como um fator de fortalecimento das instituições representativas em termos de responsabilidade e eficácia.

O problema da apropriação e captura dos recursos públicos, a propósito, também ajudou a colocar na ordem do dia a necessidade de estabelecer uma nova forma de relação entre a sociedade e o Estado. É facilmente perceptível a fragilidade dos sistemas fechados à participação social, e a tendência deles a pavimentar centros de corrupção, clientelismo, patrimonialismo e patronagem.

Habermas desempenhou um papel importante na reconciliação daquele modelo clássico procedimental (representativo) com a questão premente da participação social, ao sustentar que a atuação do governo retira a sua legitimidade de deliberação, quer dizer, do agir de forma comunicativa. ${ }^{381}$ Em outros termos, apenas seriam válidas aquelas açóes que contassem com a concordância de todos os indivíduos dos quais se exija o consenso. Assim, o procedimento ideal ultrapassa a mera homologação de governos através do voto, exigindo a consideração das diferentes identidades.

Desde o momento em que a grande maioria dos países já havia consolidado ou fizeram transições ao regime democrático, sobretudo após a terceira onda de democratização, no sul da Europa e na América latina (1970-1980), ${ }^{382}$ as atenções voltam-se à qualidade da democracia, ${ }^{383}$ isto é, às formas que não apenas garantam o direito dos cidadãos escolher quem estará autorizado a governar, mas que suponham a interferência ampla da sociedade nos processos e políticas públicas, cobrando a redenção de contas.

Seguindo o fio argumentativo de Gabriel Almond e Sidney Verba no clássico trabalho de 1963 que buscou interpretar a cultura cívica das naçōes, sucessivos estudos têm demonstrado que o engajamento cívico afeta a habilidade da democracia de entregar bons serviços, de manter os agentes públicos responsáveis e prover um governo eficiente, aspectos indissociáveis da discussão sobre qualidade do regime. ${ }^{384}$

381 HABERMAS, Jürgen. Teoria do agir comunicativo. Tradução de Paulo Astor Soethe. São Paulo: WMF Martins Fontes, 2012.

382 HUNTINGTON. Samuel P. Democracy's third wave. Journal of Democracy, v. 2, n. 2, 1991.

383 LARRY DIAMOND E MORLINO, Leonardo. The quality of democracy. CDDRL, Working Papers, n. 20, 2004.

384 FOA, Roberto Stefan; MOUNK, Yascha. The democratic disconnect. Journal of Democracy, v. 27, n. 3, 2016. 
O ponto de partida desta abordagem qualitativa é a vivência da cidadania. É dizer, que a expressão cidadã não mais se limite a um simples procedimento de validação dos poderes e determinação das grandes orientações políticas, e acrescente uma dimensão pós-eleitoral para atuação da sociedade de forma constante e incessante. Sair daquela democracia de homologação de mandatos para ingressar numa legítima democracia de vivência.

A isso corresponde um governo cada vez mais aberto aos influxos sociais, principalmente em nível local, que é o cerne do exercício da cidadania. No período que passou estudando o sistema político dos Estados Unidos, no século XIX, Tocqueville deu ênfase à participação do povo no âmbito das comunas (townships), como razão principal para as virtudes culturais e morais que encontrou na democracia norte-americana, sumarizadas no espirito comunal. Na comuna, ele afirma, centro das relações ordinárias da vida, o povo é a fonte dos poderes sociais, mas em nenhuma outra parte exerce o seu poder de maneira mais imediata. $\mathrm{O}$ que deveria manter a higidez daquela república seria fazer com que os homens tomassem parte ativa no governo da sociedade, pois "hoje em dia [estamos falando de 1835], o espirito cívico parece inseparável do exercício destes direitos políticos". Assim, o indivíduo teria na prosperidade geral a sua própria felicidade, valorizando os interesses de todos ao invés de sobrepô-los aos seus próprios. ${ }^{385}$

Acabo de chegar ao argumento que sedimenta este tópico e fundamentará as propostas que virão em seguida. A saúde da democracia depende não apenas do suporte a determinados valores-chave, como os direitos civis, mas também da participação real, efetiva e permanente de cidadãos informados, fazendo-se ouvir em quatro dimensões, ao menos: (1) emitindo opinião sobre questôes de interesse difuso e políticas públicas relevantes, expondo preferências e esclarecendo situações problemáticas; (2) inserindo as manifestações populares em todas as etapas das políticas públicas (instrução, implementação, execução, controle e avaliação), moldando a ação governamental à vontade dos grupos organizados e sub-representados, para produzir codecisóes públicas; (3) convertendo a vontade cidadã em agente de veto (veto-player) de políticas imorais ou inconvenientes, com a ressalva de que essa espécie de atuação não iniba ações políticas meramente impopulares, as quais são inevitáveis em contextos democráticos, dada a necessidade de fazer escolhas difíceis ou "trágicas" em face de recursos públicos limitados e; (4) denunciando ilicitudes e questionando práticas problemáticas, de maneira a inverter o ônus de

385 TOCQUEVILlE, Alexis de. A democracia na América. Tradução de Neil Ribeiro da Silva. 4. ed. São Paulo: Editora Universidade de São Paulo, 1987, p. 288. 
justificação por parte dos governantes sobre programas e gastos governamentais. A contestação pública permanente, aliás, permite às estruturas de controle social, ademais de interceder na implementação das políticas públicas, identificar os riscos de corrupção inerentes ao ambiente governamental, funcionando mais ou menos como um termômetro de risco dos programas de compliance nas organizações públicas.

Dentro destas quatro perspectivas, utilizando uma expressão de Bonaventura de Sousa Santos, estaríamos buscando democratizar a democracia através da participação, ${ }^{386}$ corrigindo a arritmia do accountability vertical (pelas urnas) a partir da intensificação da presença do cidadão nos processos de decisão, de forma construtiva.

Dos grandes desafios da democracia para este século - dentre eles: desestimular os riscos do populismo plutocrata, aumentar o apoio difuso aos valores democráticos etc., creio que o maior seja buscar métodos que resgatem a participação social do plano teórico das Constituições sociais, para a prática - a vivência - da relação entre Estado e sociedade civil. Em outros termos, que o impacto do engajamento cívico nas finanças públicas, no controle da corrupção e na melhoria da qualidade de vida da população, consiga deixar a imaginação coletiva, para se tornar ação coletiva.

Refiro-me à ação coletiva que converta o discurso político engajado em realidade prática, cujo endosso à integridade e censura ao particularismo consiga alterar o curso das engrenagens que alimentam a corrupção, de sorte que ela deixe de ser passivamente tolerada e passe a constituir uma escandalosa exceção aos olhos da sociedade. No entanto, estaria incorrendo no apelo retórico que me comprometi a evitar, caso não explicasse, de modo mais específico, o que estaria incluso na generalidade desta expressão.

Partindo do arcabouço teórico sobre o capital social definido por Robert Putnam, ${ }^{387}$ que intenta reunir as características que lograriam promover a mobilização

386 SANTOS, Boaventura de Sousa. Democratizar a democracia: os caminhos da democracia participativa. Rio de Janeiro. Civilização Brasileira, 2002.

$387 \mathrm{O}$ conceito está associado à conclusão que o autor expõe no capítulo 6 de sua obra, de que normas e redes de engajamento cívico afetam fortemente as prospecções para um governo efetivo e responsivo. O ponto é ilustrado da seguinte forma: quanto melhor o contexto cívico (engajamento), melhor o governo e, respondendo à pergunta que dá título ao livro, afirma que a formação de capital social, embora não seja fácil, é a chave para fazer a democracia funcionar. PUTNAM, Robert D. Making democracy work: civic traditions in modern Italy. United Kingdom: Princeton University Press, 1993, p. 163. 
apta a refletir no bom desempenho das instituições (nas palavras do autor, condições para criação de instituições representativas fortes, responsivas e efetivas), avalio o conteúdo de uma efetiva ação coletiva em diferentes enfoques, cuja consolidação pode variar conforme a robustez de cada. Primeiro, a formação de conexões interpessoais, verificada no hábito disseminado de engajamento da sociedade em ações formais e informações sobre interesses compartilhados. Segundo, a definição concreta de uma sociedade civil organizada, que estabelece uma rede de associações voluntárias, através de relações horizontalizadas, incluindo ONG's, grupos de advocacy, unióes cívicas, sociedades de ajuda mútua etc., abandonando o plano metafísico e obscuro onde se situa a denominada sociedade civil organizada, hoje. Terceiro, a consolidação da cultura cívica, refletida na permanente participação e engajamento cívico das pessoas, através das instituições formais e das mídias sociais. $^{388}$

Do ponto de vista da qualidade democrática, estes elementos são fundamentais à efetivação da ação coletiva que necessitamos para elevar o estágio de integridade do nosso ambiente institucional (das regras do jogo democrático), de vez que ativam a competição política, a responsividade dos governantes e a igualdade na repartição de recursos. ${ }^{389}$ Conforme assentou o próprio Putnam: a acumulação estável de capital social é uma parte crucial da história por trás dos ciclos virtuosos. Por outro lado, acrescentaria que o déficit deste capital, refletido na desconfiança, no isolamento e estagnação, intensifica o miasma dos círculos viciosos.

As instituições são obra dos homens. Estes não acordaram numa manhã qualquer e as encontraram funcionando. Elas são o que são como resultado da conduta humana. Desta forma, como todas as outras coisas que decorrem da ação do homem, podem ser bem-feitas ou defeituosas (defecção). Portanto, as instituições precisam de muito mais do que a mera aquiescência da sociedade, senão de sua interação constante, tal como devem ajustar-se, na medida do possível, às demandas sociais. Sociedade forte, governo forte, é o axioma que ilustra este argumento.

Por outro lado, não posso negar que determinadas circunstâncias condicionam este compromisso cívico e, por vezes, impõem fortes obstáculos a sua consolidação. É que o engajamento cívico não perfaz um elemento que funciona como que no piloto automático, mas se orienta por contextos sociais positivos (atividade)

${ }^{388}$ MUNGIU-PIPPIDI, Alina. The quest for good governance: how societies develop control of corruption. Cambridge University Press. 2015.

389 PROGEBINSCHI, Thamy; VENTURA, Tiago. Mais participação, maior responsividade? As conferências nacionais de políticas públicas e a qualidade da democracia no Brasil. Revista de Ciências Sociais, Rio de Janeiro, v. 60, n. 1, p. 7-43, 2017. 
ou negativos (passividade), de modo que, alcançado certo equilíbrio para qualquer dos lados, este status não é facilmente revertido.

Fora os níveis crescentes e alarmantes de absenteísmo nos processos eleitorais, o que denota o aumento do cinismo público em relação às instituições políticas tradicionais e o declínio do sistema formal de participação através do voto, há outros dois fatores que pré-condicionam a construção do capital social capaz de aprimorar o desempenho das institucionais nacionais. Com efeito, são dois problemas socioculturais que reclamam uma solução urgente no Brasil: a desconfiança interpessoal e o déficit de interesse político dos cidadãos.

A formação de organizações cívicas e grupos voluntários de interesse coletivo são fortemente associados à eficácia das instituições, mas elas apenas enfloram em sociedades onde haja um robusto sentimento de confiança interpessoal. Nas palavras de Albert Hirschman, a confiança funciona como um recurso moral, ${ }^{390}$ cujo estoque aumenta ao invés de diminuir na medida em que se usa, e esgota-se com o desuso. Se os indivíduos numa sociedade acreditam que seus concidadãos atuarão com honestidade e altruísmo em prol do interesse coletivo, eles tendem mais facilmente a engajar-se de modo voluntário em redes, para buscar este mesmo tipo de interesse, começando por estruturas horizontais como associações de bairro, cooperativas etc. É dizer, a confiança lubrifica a cooperação social para resolver problemas que exigem ações coletivas, bem como diminui o espaço para oportunismos.

Ao reverso, o efeito moral que decorre de uma sociedade sequiosa destes laços sociais é um individualismo nocivo, pelo qual as pessoas somente darão com uma mão, se simultaneamente receberem algo com a outra. Faltar-lhe-á uma noção clara de interesse coletivo e bem-estar social, pois estarão sobrepostos pela necessidade de competição em relação aos outros, e até certo ponto às custas dos outros, pois certamente prevalecerá (como, aliás, prevalece entre nós) as relações verticais baseadas no clientelismo. A estreita ideia de moral privada segundo a qual se a farinha é pouca, meu pirão deve vir primeiro, alimenta o paroquialismo que degrada há séculos nossas instituiçôes. É de se notar, desta forma, que o conhecimento sobre os diferentes interesses que compõe o grupo do qual fazemos parte (seja na comunidade local, no trabalho etc.), nos move para além dos interesses particulares, reforçando normas sociais que rejeitam condutas desonestas.

Quanto a um último aspecto, numa sociedade caracterizada por estas redes fortes de engajamento cívico, onde a maioria das pessoas respeita normas sociais e

390 HIRSCHMAN, Albert O. Getting ahead collectively: grassroots experiences in Latin America. New York: Pergamon Press, 1984, p. 57. 
tem um apreço especial à coisa pública, é mais fácil detectar e dissuadir eventuais maçãs-podres, de modo que estes comportamentos se tornam mais arriscados, e menos tentadores.

Entretanto, este é um problema a ser superado, porquanto o panorama brasileiro, em termos de confiança entre os indivíduos, é historicamente desfavorável. Os índices de confiança interpessoal e confiança nas instituições políticas são similarmente negativos. Segundo a mensuração presente da sexta onda (2010-2014) do World Values Survey, 92,2\% dos brasileiros acham que se deve ter muito cuidado ao confiar nas pessoas. Por outro lado, apenas $7,1 \%$ acredita que a maioria das pessoas são confiáveis. A mesma pesquisa revela ainda um patamar extremamente baixo (em média de $80 \%$ de dispersão) no tocante à formação/participação em associaçôes voluntárias (profissionais, esportivas, de meio ambiente, de consumidores, artísticas, educacionais etc.). ${ }^{391}$

Outro pressuposto sociocultural à participação é o interesse político. Embora a adesão dos brasileiros à democracia tenha aumentado em uma perspectiva histórica, o envolvimento político é preocupantemente baixo. Segundo os dados da WVS (2010-2014), ao responder à pergunta: em que medida o(a) Sr.(a) se interessa por política? $62,5 \%$ dos brasileiros não tem nenhum interesse ou não tem muito interesse no assunto. $\mathrm{O}$ mais surpreendente é que os jovens até 29 anos concentra maior desinteresse $(63,6 \%)$. Comparando com os dados referentes ao período compreendido entre 1990 a 1994, percebe-se um aprofundamento da descrença, que marcava à época 53,8\%. A tendência, contudo, não é exclusivamente brasileira, haja vista constatar-se em nível mundial o declínio de interesse na política e de suporte às instituiçõos formais da democracia. ${ }^{392393}$

Os mecanismos políticos não agem por si mesmo, tanto quanto um arreio não guia um cavalo sem o cavaleiro. Mesmo dispondo do melhor arranjo institucional possível, o público inerte conseguirá extrair poucas vantagens concretas. E o que é pior, como ilustra Douglass North, tais padrões de inércia são retroalimentares. ${ }^{394}$ O que ele quer dizer é que é quase sempre mais fácil para determinada pessoa se adaptar às regras do jogo em vigor (ainda que imorais), do que buscar mudanças

391 World Values Survey. WV6. (2010-2014) Brazil. v. 2016.01.01.

392 World Values Survey. WV2. (1990-1994) Brazil. v. 2014.04.18.

393 FOA, Roberto Stefan; MOUNK, Yascha. The democratic disconnect. Journal of Democracy, v. 27, n. 3, 2016.

394 NORTH, Douglass C. Institutions and a transaction costs theory of exchange. In: ALT, James E.; SHEPSLE, Kenneth. Perspectives on positive political economy. New York: Cambridge University Press, 1990. 
-• Finanças públicas: travessia entre o passado e o futuro

substanciais. Em terra de passividade, quem busca promover reformas é louco. Calha perfeitamente a sentença de Aristóteles: o vulgo zanga-se menos por estar excluído do governo do que por ver os magistrados viverem às custas do tesouro público. É até muito cômodo dispor todo o tempo para cuidar apenas dos negócios particulares. ${ }^{395}$

A lei natural nos permite deduzir que coisas abandonadas inevitavelmente se deterioram. Desenvolvimento pressupóe cultivo. $\mathrm{O}$ mesmo vale para a governança. Instituiçôes que funcionam a despeito da presença do cidadão, em termos de qualidade democrática, estão escrevendo sobre a água, pois se acaso fosse possível para o povo ser bem governado sem a sua concomitante participação, este seu bom governo não duraria mais do que uma plantação no semiárido nordestino. À sombra da sociedade, logo se converteria em instrumento de tirania ou corrupção, ou ambos.

A democracia praticada desta maneira desleixada, ao inverso de representar uma garantia contra governos imorais ou irresponsáveis, converte-se num gatilho a mais em seu funcionamento. Isso porque aqueles que poderiam realizar uma administração boa e íntegra se afastam e são repostos por indivíduos que substituem a vontade popular pelos interesses particulares.

Não é algo, portanto, que seja equacionado exclusivamente com determinada engenharia política, mas que depende enfim de certas condições sociais (incontroláveis, admito) que propiciem o engajamento dos cidadãos nos assuntos coletivos. ${ }^{396}$ Contudo, instrumentos que inovem o sentido da participação social podem desenvolver este envolvimento e proporcionar melhorias substanciais.

$\mathrm{Na}$ ideia sobre as condições gerais para o exercício do status de cidadania ativa, ${ }^{397}$ já tive a oportunidade de apresentar o pressuposto cognitivo, seja no tocante à iminência da abertura dos dados públicos ao conhecimento do povo (dimensão da transparência), seja no que diz respeito à qualificação do cidadão no entendimento acerca dos processos e regras políticas (dimensão da educação política). De igual modo, acabo de abordar neste capítulo o pressuposto sociocultural que atine ao recurso moral da confiança - social e interpessoal - e o interesse político, materializados na formação do capital social. Falta, portanto, que examinemos o que seria o último pressuposto para participação efetiva: o instrumental, referente aos

395 ARISTÓTELES. A Política. 2. ed. São Paulo: Edipro, 2010, p. 161.

396 MIGUEL, Luís Felipe. Representação democrática: autonomia e interesse ou identidade e advocacy? Lua Nova, São Paulo, n. 84, p. 353-364, 2011.

397 WILSON GOMES. Internet e participação política em sociedade democráticas. Revista FAMECOS, Porto Alegre, n. 27, 2005. 
meios adequados para assegurar voz e espaço à sociedade no intercurso de decisóes coletivas.

A Constituinte de 1988, influenciada pelo forte apelo de redemocratização pós-regime militar, ademais de reconhecer a emanação popular do poder político em seu art. $1^{\circ}$, parágrafo único, aumentou as possibilidades de influência formal dos cidadãos no processo político, institucionalizando, no art. 14, o sufrágio através do voto, a iniciativa popular, o plebiscito e o referendo, bem como no art. 29, a possibilidade de participação de entidades representativas no planejamento local e a possibilidade de destinação de denúncias ao Tribunal de Contas, no art. 74, $\$ 2^{\circ}$.

Contudo, não obstante a expansão promovida pela Constituição nas vias formais (convencionais) de participação popular, a vivência democrática revelou uma reduzida efetividade prática destes mecanismos, parte em razão de suas próprias limitações, parte como resultado da desídia dos administradores públicos. Hoje, a sensação generalizada é de profunda frustração com a promessa original. É que as oportunidades que os canais convencionais de participação provêm aos cidadãos, para que façam valer sua vontade no curso das decisões políticas, são escassas, além de produzirem consensos frágeis que não obrigam, nem constrangem os encarregados pela decisão.

Ocorre que no contexto de reapropriação da soberania pela sociedade, devem-se pavimentar canais que escapem ao modelo formal-tradicional de participação, descortinando um novo horizonte de caminhos não convencionais de atuação cidadã. Refiro-me à não convencionalidade, neste caso, como categoria que inclui mecanismos à parte daqueles instrumentos previstos pela Constituição, seja os provenientes da própria sociedade (p.ex.: grupos de advocacy, observatórios sociais etc.), seja os institucionalizados pelo poder público (p.ex.: orçamento participativo, canais de denúncia cidadão, audiências públicas etc.).

Neste contexto, na linha do complemento eletrônico à ideia de governo aberto (e-government), convém atentar para as potenciais contribuições que a internet pode fornecer no sentido de ampliar as possibilidades institucionais ou não institucionais de engajamento cívico, renovando os repertórios da atuação popular. Inobstante o fundado receio de que as redes sociais pudessem pulverizar a opinião pública, retirando-lhe a consistência e a identidade, é certo que as novas tecnologias de informação permitem, por um lado, superar empecilhos inerentes à participação social, tal como a necessidade de deslocamento, tempo (cada vez menos disponível), além da redução de custos e do contato com burocracias despiciendas. Por outro, produzem novos estímulos à interação da sociedade entre si, através do fluxo mais célere de comunicação pelas mídias sociais, e da sociedade com o governo, 
por intermédio de vias que simplifiquem a canalização das demandas e facilitem o controle social. Além do mais, a abrangência quase ilimitada das possibilidades tecnológicas estende a audição governamental até vozes que estão geralmente à margem dos debates, de comunidades excluídas por fatores econômicos, sociais ou étnicos. Ser deixado de fora das deliberaçōes é um grande desencorajamento ao indivíduo que, à falta de alternativas, se entrega à dependência aos árbitros de seus destinos.

Proponho, no entanto, uma abordagem realista, que ao invés de focalizar a túnica dos mecanismos de participação, enfatize o verdadeiro impacto que eles promovem nos processos de tomada de decisão. Com efeito, a questão aqui é mais descritiva (como é), do que prescritiva (como deveria ser), de modo que possamos avaliar se, de fato, os canais de interação conseguem ou não promover o engajamento cívico e a consequente melhoria de qualidade das instituições.

Por trás do aparente crescimento dos instrumentos participativos, há fragilidades que colocam uma interrogação sobre até que ponto a contribuição cidadã está realmente sendo levada em conta, e não servindo de anteparo para campanhas eleitorais, ou como pretexto democrático para sobrepor clientelismos.

$\mathrm{Na}$ verdade, essa distinção entre aparência e realidade em termos de participação foi bem colocada por Jenny Pearce, ao separar, com base na densidade ou intensidade da abertura governamental, o contexto que chamou governo participativo, o qual apenas oportuniza às comunidades locais a expressão de opiniões, permanecendo centralizado, todavia, o poder decisório, do contexto ideal de democracia participativa que, noutro viés, baseia-se no envolvimento direto, duradouro e efetivo dos cidadãos, atendendo especialmente a fração mais vulnerável da sociedade. ${ }^{398}$

Não seria descomedido associar o Brasil ao primeiro modelo, embora reconheça aprimoramentos recentes. Todavia, mesmo em circunstâncias nas quais se verifica um incremento nos meios formais de participação, tal aumento, para ser realmente eficaz do ponto de vista do alcance e penetração da voz social, precisa fazer-se acompanhar pela mudança da forma de atuação política. Sabemos, todavia, do apego do sistema político a prerrogativas e espaços de opacidade nas tomadas de decisão, e a dificuldade de cedê-los em benefício das instâncias participativas.

398 PEARCE, Jenny. Participation and democracy in the twenty-first century city. Badford: Palgrave, 2010. 
O que precisamos, portanto, é da consolidação dos canais não convencionais que estabeleçam incentivos à calibragem da participação em todas (todas mesmo!) as etapas do processo de confecção das políticas públicas. ${ }^{399}$

Porquanto o núcleo do contrato social repousa nas decisões sobre alocação e dispêndio dos recursos públicos, e a concepção holística de corrupção que adotamos diz respeito justamente ao modelo particularista pelo qual estes recursos são distribuídos, o orçamento é o lugar mais adequado para buscarmos respostas às formas de interação entre a sociedade e o poder público, a fim de promover igualdade, justiça e a redução de privilégios patrimonialistas. É dele, portanto, que irei falar adiante.

No processo orçamentário, cuja função primordial consiste em estabelecer um projeto crível de governança, quem é - e quem não é - incluído na mesa de negociação, pode determinar se os formuladores de políticas públicas alcançarão soluções eficazes, ou se farão do orçamento um balcão de negócios privados. A boa-governança, portanto, depende muito da disposição dos tomadores de decisão em preencher o espaço público com a opinião social de diferentes grupos. Barreiras eventualmente erguidas e o acesso desigual às instâncias de poder determinam o hiato entre a má e a boa governança. ${ }^{400}$

Por exemplo, um dos elementos-chave para compreender o bom desempenho da governança em Botswana, na África, cujo índice de percepção da corrupção é melhor que o de países como Polônia, Eslovênia, Espanha e Geórgia, encontra-se na abertura dos processos de planejamento e orçamentação, envolvendo comunidades, estruturas locais, atores não estatais e as instituiçōes políticas. No âmbito federal, todas as alocações são incluídas em um plano nacional de desenvolvimento, o qual é discutido abertamente durante longo período. ${ }^{401}$

Dentro deste contexto, o Brasil é visto como um centro de inovações, sobretudo a partir da concepção dos procedimentos de orçamento participativo, na década de 1990, que permitiram a deliberação local sobre como seriam realizadas parcelas do orçamento referentes a determinada despesa de investimento. A ideia,

399 Vejo estes incentivos em duas direçôes: de dentro para fora, aludindo à vontade e capacidade dos administradores públicos em franquear canais de interação e estimular a ocupação destes espaços públicos pelos cidadãos, e de dentro para fora, a partir da sociedade civil, pois, sabendo que dificilmente esta abertura será inteiramente espontânea, exerce pressão sobre os agentes responsáveis pelas decisões, além de conceber mecanismos próprios de participação e influência.

${ }^{400}$ Relatório de Desenvolvimento do Banco Mundial, 2017.

${ }^{401}$ MUNGIU-PIPPIDI, Alina. The quest for good governance. How societies develop control of corruption. Cambridge University Press, 2015. 
difundida pelos municípios brasileiros, foi recebida como boa-prática governamental pelos fóruns internacionais e incorporada, desde então, por administrações públicas mundo afora. Todavia, perdeu o ímpeto e eficiência em seu próprio berço, conforme atesta Carole Pateman, ao examinar as experiências de OP três décadas após as implementaçóes originárias, segundo a qual, a maioria dos exemplos de orçamento participativo são facilmente associados a estruturas de autoridade, e os cidadãos não estão participando adequadamente nas decisões sobre o orçamento regular da cidade. ${ }^{402}$ De fato, o que se percebe atualmente é que o orçamento participativo se converteu em procedimentos formais de consulta, cujo papel principal é dissimular o endosso popular sobre alocações corporativistas e permitir ao gestor que atravesse a deliberação das câmaras legislativas.

Ademais, outras disposições legais preveem exigências de deliberação e consulta à sociedade como condição, complementação ou conclusão de validade de determinados atos administrativos, tal como a LRF ${ }^{403}$ e o Estatuto da Cidade, ${ }^{404}$ que padecem, contudo, de semelhante má estruturação, além de não serem completamente inclusivos.

Esta discrepância (formal-material) que sobrelevei constitui o objeto de pesquisa do International Budget Partnership (IBP), o qual avalia, periodicamente, a qualidade e abertura do orçamento de vários países. No informe publicado em 2017, observa-se que aproximadamente $80 \%$ dos 115 países analisados possuem determinadas ferramentas de participação orçamentária, embora seja necessário, segundo o IBP, melhorar a inclusão dos mecanismos existentes e implementar meios similares em outras etapas do processo orçamentário. 405

A pesquisa revela a dimensão do problema da participação real. Segundo o IBP, dentre os 115 países incluídos na pesquisa sobre abertura governamental, nenhum deles proporciona oportunidades de participação que possam ser consideradas adequadas (no caso, aquelas que alcançarem pontuação superior a 61 ou mais).

402 PATEMAN, Carole. Participatory democracy revisited. Perspectives on Politics, v. 10, n. 1, 2012, p. 14.

${ }^{403}$ Lei Complementar n. 101/2000, art. 48, parágrafo único, inciso I. Incentivo à participação popular e realização de audiências públicas, durante os processos de elaboração e discussão dos planos, leis de diretrizes orçamentárias e orçamentos.

${ }^{404}$ Lei n. 10.527/2001. Art. 2o, II. Gestão democrática por meio de participação da população e de associações representativas dos vários segmentos da comunidade na formulação, execução e acompanhamento de planos, programas e projetos de desenvolvimento urbano.

405 INTERNATIONAL BUDGET PARTNERSHIP. Encuesta de Presupuesto Abierto 2017. Disponível em: <https://www.internationalbudget.org/wp-content/uploads/open-budget-survey-2017-report-spanish.pdf>. Acesso em: 28 fev. 2018. 
Ademais, 111 países proporcionam o que a instituição considera como poucas oportunidades ou não oferecem oportunidades à participação do público (incluem os países com pontuação inferior a 41). Interessante destacar que os países com pontuação em participação são, também, os países mais transparentes, e que não há baixa transparência associada a pontuações moderadas no quesito participação, demonstrando a relação de condicionalidade entre os dois elementos.

Especificamente, quanto ao Brasil, a organização recomenda a criação e institucionalização de expedientes para além de encontros informativos e consultas, porém arenas onde a sociedade possa realmente influenciar as decisóes.

Há espaço para mudanças! Trabalhadas corretamente, as iniciativas de inserção do povo acompanhamento da alocação de recursos públicos garantem que o governo seja mais responsivo às demandas e responsável às obrigações de integridade.

O mais importante é que a participação abrace todas as quatro etapas do ciclo de orçamentação, tanto no âmbito do Poder Executivo (formulação e execução) quanto no contexto do Poder Legislativo (aprovação e fiscalização), por intermédio de ferramentas práticas e legíveis, que possibilitem a interação direta das comunidades interessadas. Um exemplo interessante desta cooperação encontra-se na Coreia do Sul, que associou o sistema de reportes (whistleblowing) à fase de controle da execução orçamentária, criando um centro de denúncias específicas sobre desperdícios orçamentários, o Budget Waste Reporting Center. Compete ao organismo receber e investigar as denúncias de qualquer cidadão sobre casos de uso ineficiente ou desperdício dos recursos orçados, excluídas as hipóteses que configurem corrupção, que estão abrangidas na competência da Agência Anticorrupção e de Direitos Civis da Coreia. Se restar constatado que houve de fato o desperdício financeiro, o reportante poderá obter uma recompensação fixa que varia de US\$ 175 até US\$ 50.000.406

Outro aspecto essencial e pouco realizado é a necessidade de prover feedbacks informativos de participação, expondo ao cidadão como suas contribuições foram incorporadas e traduzidas em ação política, o que foi deixado para trás e o porquê. Ainda que a decisão final permaneça nas mãos da autoridade pública, ela deve prestar contas sobre o papel desempenhado pelos insumos (inputs) públicos na definição das propostas, e como elas estão sendo implementadas na prática. ${ }^{407}$ $\mathrm{O}$ processo de motivação sobre os insumos e justificação das escolhas reduz a

\footnotetext{
${ }^{406}$ INTERNATIONAL BUDGET PARTNERSHIP. Encuesta de Presupuesto Abierto, 2017. ${ }^{407}$ INTERNATIONAL BUDGET PARTNERSHIP. Rethinking Citizen Engagement, 2016.
} 
- Finanças públicas: travessia entre o passado e o futuro

percepção de arbitrariedade sobre as decisões estatais. Neste aspecto, os Tribunais de Contas exercem um papel elementar, na medida em que as competências que lhe são asseguradas pela Constituição Federal permitem garantir a efetivação necessária para que decisões provenientes do consenso popular sejam respeitadas mais à frente (art. 71, VIII, da CRFB/88), eliminando-se espaços de discricionariedade que colocam o gestor como árbitro único do orçamento público, bem como sustar atos que contrariem a vontade popular consolidada nos canais de deliberação (art. 71, X, da CRFB/88). 